\title{
Theoretical and Experimental Results on the Recovery of Potato Processing Residuals by Anaerobic Digestion
}

\begin{abstract}
ANDREEA D. DIMA'1,2, CARMEN MATEESCU1*, OANA C. PARVULESCU2*, EDUARD M. LUNGULESCU1', NICOLETA O. NICULA ${ }^{1}$ ${ }^{1}$ National Institute for Research and Development in Electrical Engineering ICPE-CA, 313 Splaiul Unirii, 030138, Bucharest, Romania

2University Politehnica of Bucharest, Chemical and Biochemical Engineering Department, 1-3Gheorghe Polizu, 011061, Bucharest, Romania

Anaerobic digestion of organic matter with high moisture content has proven to be a suitable method for disposal of wet organic residuals with several advantages compared to other treatment technologies. This paper aimed at evaluating the theoretical and experimental biomethane potential of food processing residuals that are responsible fornegative environmental impact, with exemplification for the potato processing waste. The biomethane potential is a useful parameter to assess the economic efficiency of anaerobic digestion processes as it can considerably influence the efficiency and the economic feasibility of the energy recovery technologies. Both experimental and theoretical biomethane potentials of potato waste in mesophilic anaerobic digestion as well as biodegradability of the substrate were estimated. Moreover, effects of microalgal extract addition on the digestion of potato waste were examined in an attempt to stimulate the anaerobic digestion. Cone model and a modified Gompert model were used to predict the dynamics of biomethane production.
\end{abstract}

Keywords: anaerobic digestion, biogas, methane, potato waste, microalgae, kinetic model

The continuous demographic growth has generated, among other concerns, increased food demand and intensive development of the global food industry. As a consequence, the production of food waste and various processing residuals has significantly increased [1]. Residuals are defined as those materials which remain after processing a primary product. In some cases, residuals are utilized for by-products, e.g., animal feed, and therefore they do not necessarily cause problems of disposal. However, residual materials frequently have no utility and must be disposed of in such a manner that does not induce environmental pollution and public health concerns [2].

Such residuals are rich in organic matter and have a high moisture content, that make them have a high perishability; therefore, their quick removal is mandatory [3]. On the other hand, food processing wastes have an important potential for conversion into useful products or even can be used as raw materials for other industries; they can also be recovered as feed after some specific biological pretreatments.

Anaerobic digestion is an effective biochemical degradation method that is widely used for the treatment and energy recovery from many types of biomass feedstock including crops, wood, grass and other plants, agricultural and forestry residues, organic components from municipal or industrial wastes, etc. [4]. This approach has been proven to be a more adequate method for disposing wet organic waste than other waste treatment techniques, e.g., incineration, pyrolysis [5, 6]. Anaerobic digestion can bring several economical and environmentally friendly benefits, which make it applicable to industrial energy generation processes, combining renew able energy recovery of biogas with the sustainable treatment of a huge variety of biodegradable wastes from municipal wastewater treatment plants, agriculture, household or industrial processes [ 7-10].
An important share of the total amount of waste from the processing of food is represented by the wastes of fruits and vegetables which are mostly disposed along with the municipal solid wastes in landfills or dump-sites; this creates a breeding ground for pests and disagreeable odours [11]. Valorisation of food processing residuals for biogas production would be a proper option in reducing the amount of waste that needs to be collected and disposed of as well as in protecting ecosystem diversity and forest resource from degradation $[12,13]$.

One of the most important agricultural crops for human consumption after wheat, rice, and maize is potato (Solanum tuberosum L.). Cca. 53 million tonnes of potatoes were harvested in the EU in 2015, whereas the overall value of EU processed potato production reached 9.4 billion EUR in 2015 [14]. During potato processing, 15-40\% represents production loss in the form of potato peel waste [15].

Some authors investigated the best managementoption for the resulting potato peels by looking at the climatic impact based on contribution of greenhouse gases emission from generation and dumping of huge quantities of potato peels [12]. Also, many studies were made on potato peel waste application possibilities in order to minimize industrial waste amount and find suitable application for this residual as a by-product [15]. On the contrary, few experimental researches have been reported on anaerobic digestion of potato residuals to produce biomethane, since this organic substrate was usually regarded as feedstock for the production of ethanol due to the high content of soluble carbohydrates [16, 17].

The aim of this paper was to assess both theoretical and experimental biomethane yields from the anaerobic batch digestion of potato peel residuals and to enrich the information currently available in the scientific literature regarding the potential for energy recovery from this residual material generated by the food industry. Moreover, the obtained results intend to draw attention of farmers and industrial food processors towards the potential benefit

* email: carmen.mateescu@icpe-ca.ro, oana.parvulescu@yahoo.com 
of energy recovery from waste materials by anaerobic digestion. In addition, co-digestion of potato waste and microalgal extracts from Chlorella sp. and Spirulinasp. was investigated in order to evaluate the effect of microalgae on the biogas production. Microalgae with consistent nutritional quality can be produced continuously and independent to farm land. Total biomass or their residuals after biodiesel conversion are suitable feedstock alternatives for biomethane production. Previous studies reported synergetic effects of microalgae co-digestion with sewage sludge at mesophilic temperature in both batch and semi-continuous tests, while microalgae also stimulated the anaerobic digestion of agro-industrial residuals as co-digestion material [18, 19].

\section{Experimental part}

\section{Feedstock and inoculum}

Potato residuals, consisting of $70 \%$ peel and $30 \%$ pulp, were ground to a size of 2-4 mm and then manually homogenized and stored in the refrigerator until the sample was analyzed and prepared for anaerobic digestion, after mixing with cow manure as inoculum. Microalgal extracts of Chlorella sp. and Spirulina sp., resulted from lipid extraction, were provided by National Institute for Research $\&$ Development in Chemistry and Petrochemistry ICECHIM Bucharest.

\section{Waste composition analysis}

The characterization of the potato waste was carried out according to the APHA methods for total solids (TS), volatile solids (VS), and pH [20]. Elemental analysis was performed using a Perkin Elmer 2400 Series II CHNS/O Elemental Analyzer.

\section{Experimental set-up and procedures}

The anaerobic digestion tests were conducted in 500 $\mathrm{mL}$ dark glass serum bottles sealed with butyl rubber stoppers and connected via PTFE tubes to Supel-Inert MultiLayer Foil gas bags with a volume of $5 \mathrm{~L}$. The fermentation process was provided with single feeding in batch mode until biogas emission significantly decreased to less than $1 \%$ from the total production. The organic substrate to be fermented was prepared from potato waste, inoculum, and water, the mixture humidity being in the range of 90 $92 \%$. The influence of microalgae addition to the potato anaerobic digestion substrate was investigated for concentrations of $5 \%$ extract of either Chlorella sp. or Spirulina sp. with respect to potato waste.

Anaerobic conditions were created by flushing argon for $3 \mathrm{~min}$ to ensure the complete removal of the air from headspace and substrate layer. The fermentation vessels were immediately closed with butyl rubber stoppers and sealed with paraffin film. The $\mathrm{pH}$ of the medium was measured by a pH meter (Hanna Instruments, model pH 211) and the acidity was adjusted by dropping $1 \mathrm{~N} \mathrm{NaOH}$ solution until $\mathrm{pH}$ ranged within 7-7.5.

The bottles were placed in a climatic chamber and kept at $37 \pm 1^{\circ} \mathrm{C}$ during the whole time of 21 days required for a complete anaerobic digestion of the substrate. The homogenisation was manually insured by softly shaking the bottle twice a day. The biogas volumes were measured by liquid displacement which is a simple and reliable method [21]. The experimental set-up used for the anaerobic digestion tests is presented in figure 1.

The methane standard and biogas samples were analyzed using a Varian 450-GC gas chromatograph (Agilent Technologies), equipped with a flame ionization

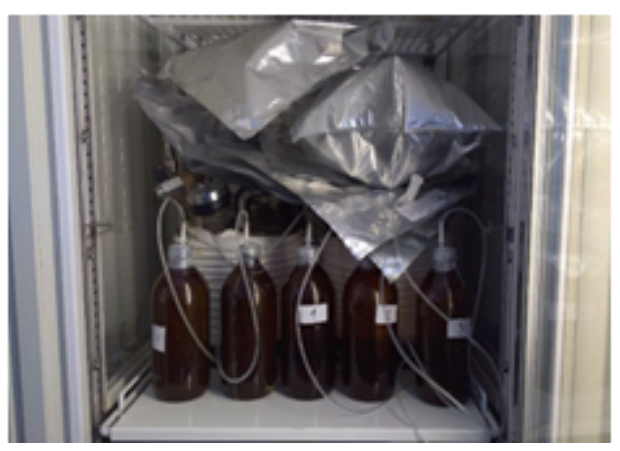

Fig. 1.

Laboratory experimental set-up for the anaerobic digestion tests

detector (FID), 6-ports sampling valve (Valco Instruments Co. Inc.), and a split/splitless injector. FID temperature was $150^{\circ} \mathrm{C}$ and gas flow rates through the system were 25,30 , and $300 \mathrm{~mL} / \mathrm{minfor} \mathrm{N}_{2}, \mathrm{H}_{2}$, and air, respectively. The injected volume was $0.125 \mu$ [ with a split ratio of $40: 1$, while the injector temperature was $50^{\circ} \mathrm{C}$. The column set was composed of a low polarity CP-Sil 5CB Chrompack capillary column ( $100 \%$ polydimethylsiloxane, $15 \mathrm{~m} \times 0.25 \mathrm{~mm}$, $0.25 \mu \mathrm{m}$ film thickness).

In order to calibrate the GC equipment for determination of methane content in biogas samples, a standard gas of methane (Linde) was used. The calibration curve was obtained by measuring the methane peaks area (retention time of methane: $4.774 \mathrm{~min}$ ) from the GC chromatograms recorded using different $\mathrm{CH}_{\text {, }}$ air concentration ratios, i.e., 100:0, 75:25, 50:50, and 0:100.

\section{Theoretical biochemical methane potential}

Theoretical biochemical methane potential of the material, TBMP ( $\mathrm{mL} / \mathrm{g} \mathrm{VS}$ ), can be estimated using eqs. 1 and 2 [22-28], where $V_{m}=22.4 \mathrm{~L} / \mathrm{mol}$ represents the molar volume of the gas under standard conditions, $M_{C_{s} H_{s} O_{e} N_{d} S_{c}}(\mathrm{~g} / \mathrm{mol}$ ) the molar mass of biomass (given by eq. 3), and $M_{i}(\mathrm{~g} / \mathrm{mol})$ the molar mass of element $i(\mathrm{C}, \mathrm{H}, \mathrm{O}$, $\mathrm{N}$, and S). Subscripts $a, b, c, d$, and e in the chemical formula $\mathrm{C}_{a} \mathrm{H}_{0} \mathrm{O}_{c} \mathrm{~N}_{d} \mathrm{~S}_{e}$ can be determined based on the elemental analysis.

$$
\begin{gathered}
\mathrm{C}_{a} \mathrm{H}_{b} \mathrm{O}_{c} N_{d} \mathrm{~S}_{e}+\left(a-\frac{b}{4}-\frac{c}{2}+\frac{3 d}{4}+\frac{e}{2}\right) \mathrm{H}_{2} \mathrm{O} \rightarrow\left(\frac{a}{2}+\frac{b}{8}-\frac{c}{4}-\frac{3 d}{8}-\frac{e}{4}\right) \mathrm{CH}_{4}+ \\
+\left(\frac{a}{2}-\frac{b}{8}+\frac{c}{4}+\frac{3 d}{8}+\frac{e}{4}\right) \mathrm{CO}_{2}+d \mathrm{NH}_{3}+e \mathrm{H}_{2} S \\
T B M P=\frac{1000 V_{m}\left(\frac{a}{2}+\frac{b}{8}-\frac{c}{4}-\frac{3 d}{8}-\frac{e}{4}\right)}{M_{\mathrm{C}_{s} H_{b} O_{s} N_{s} S_{s}}} \\
M_{C_{s} H_{z} O_{e} N_{d} S_{s}}=a M_{C}+b M_{H}+c M_{O}+d M_{N}+e M_{S}
\end{gathered}
$$

\section{Methane-based biodegradability}

Methane-based biodegradability of the substrate, $B D(\%)$, is calculated using eq. 4, depending on the experimental biochemical methane potential (EBMP) and TBMP $[5,26$, 28, 29].

$$
B D=100 \frac{E B M P}{T B M P}
$$

\section{Kinetic modelling}

Modelling is essential to design, control, and optimize a process as well as to understand its mechanisms [28, 30, 31]. Cone and modified Gompertz models have been widely used to predict the dynamics of biomethane production $[26,28,32,33]$. They are described by eqs. 5 and 6 , where $P_{M}(t)(\mathrm{mL} / \mathrm{g}$ VS) is the cumulative methane 
production at time $t(\mathrm{~d}), P_{\mu m}(\mathrm{~mL} / \mathrm{g}$ VS) the maximum cumulative methane production, $k\left(\mathrm{~d}^{-1}\right)$ the hydrolysis rate constant, $n$ the shape factor, $r$ ( $\mathrm{mL} / \mathrm{g}$ VS/d) the maximum methane production rate, and $\lambda(d)$ the lag-phase time.

$$
\begin{gathered}
P_{M}(t)=\frac{P_{M, m}}{1+(k t)^{-n}} \\
P_{M}(t)=P_{M, m} \exp \left\{-\exp \left[\frac{r_{m} \exp (1)}{P_{M, m}}(\lambda-t)+1\right]\right\}
\end{gathered}
$$

\section{Results and discussions}

Characteristics of potato waste

Physicochemical analysis results of potato waste are summarized in table 1, where TS represents total solids, MC moisture content, and VS volatile solids.

Theoretical biochemical methane potential

Subscripts $a, b, c$, and $d$ in the chemical formula $\mathrm{C}_{a} \mathrm{H}_{b} \mathrm{O}_{c} N_{d}$ were determined based on the data specified in

\begin{tabular}{|l|c|}
\hline Parameter & Value \\
\hline TS (\%) & 17.8 \\
\hline MC (\%) & 82.2 \\
\hline VS (\%) & 94.8 \\
\hline Ash (\%) & 5.2 \\
\hline $\mathrm{C}(\%)$ & 40.07 \\
\hline $\mathrm{H}(\%)$ & 5.90 \\
\hline $\mathrm{O}(\%)$ & 47.55 \\
\hline $\mathrm{N}(\%)$ & 1.28 \\
\hline $\mathrm{S}(\%)$ & 0 \\
\hline $\mathrm{C} / \mathrm{N}$ & 31.31 \\
\hline
\end{tabular}

Table 1

CHARACTERISTICS OF POTATO WASTE

table 2, where $c_{i}$ ( $\%$ of organic dry matter), $x_{i}(\mathrm{~g} / \mathrm{g})$, and $M_{i}$ $(\mathrm{g} / \mathrm{mol})$ are the percent concentration, mass fraction, and molar mass of element $i$, whereas $R$, represents the ratio between $x$ and $M$. According to eqs. 2 and 3 , the values of $M_{\mathrm{C}_{s} \mathrm{H}_{s} \mathrm{O}_{\mathrm{S}} \mathrm{N}_{S} \mathrm{~S}_{f}}$ and TBMP determined depending on tabulated levels of subscripts, i.e., $a=36.51, b=64.03, c=32.53$, and $d=1$, were $1037.53 \mathrm{~g} / \mathrm{mol}$ and $383 \mathrm{~mL} / \mathrm{g} \mathrm{VS}$. TBMP is an important parameter for providing essential information before developing biogas projects at industrial scale, allowing comparison between different feedstocks [22].

\section{Experimental biogas and biomethane production}

Biogas volume, methane content in the biogas generated by the organic substrate subjected to anaerobic digestion in mesophilic thermal regime, and methane volume vs. digestion time $(t)$, expressed in days (d), are shown in table 3. Tabulated results highlight that the biogas production was accelerated in the first 7 days of the fermentation process, although the generated biogas showed a low concentration of biomethane and consisted mainly of carbon dioxide. Biomethane concentrations in biogas had a significantrise only with the increase in biogas volume, indicating that the biochemical processes of anaerobic digestion reached its final stage, the methanogenesis. Increasing concentrations of biomethane in biogas were recorded along the 21-days experiment, after which the biogas production declined sharply, indicating a depletion of organic components in the fermentation mass.

Variations in time, $t(d)$, of experimental cumulative biogas volume, $V_{B \text { exp }}(\mathrm{mL})$, and experimental cumulative methane production, $P_{M, \text { exp }}(\mathrm{mL} / \mathrm{gVS})$, are presented in figures 2 and 3 . Depicted data, reveal that the potato waste sample without the addition of microalgae generated lower cumulative biogas volumes, but significantly higher cumulative methane productions compared to potato samples with the addition of microalgal extracts. Although comparative trials aimed at identifying a possible stimulating effect of microalgal extracts in favour of biomethane production, as indicated in other studies $[18,19]$, the results revealed an inhibitory effect for methanogenesis.

Microalgae are composed of proteins, carbohydrates, lipids, and many other valuable compounds, e.g., pigments, antioxidants, vitamins, fattyacids. These are considered to be suitable feed and source of nutrients for the fermentative microorganisms, generating energy-intensive fermentation products [34].

On the other hand, microalgae biomass resulting from lipid extraction contains higher protein amount than crude biomass, which could inhibitthe methanogenesis process. The inhibiting effect could be caused by the excess of ammonia generated during the decomposition of nitrogenous compounds [35]. Also, inhibitory effects can be explained by the rich content of stabilizing compounds which oppose the macromolecular structures biodegradation of the substrate.

\begin{tabular}{|c|c|c|c|c|c|c|}
\hline Element $i$ & $\begin{array}{c}\text { Concentration } \\
c_{i}(\%)\end{array}$ & $\begin{array}{c}x_{i} \\
(\mathrm{~g} / \mathrm{g})\end{array}$ & $\begin{array}{c}M_{i} \\
(\mathrm{~g} / \mathrm{mol})\end{array}$ & $\begin{array}{c}R_{i}=x_{i} / M_{i} \\
(\mathrm{~mol} / \mathrm{g})\end{array}$ & \multicolumn{2}{|c|}{$R_{i} / R_{N}$} \\
\hline $\mathrm{C}$ & 42.27 & 0.423 & 12.0107 & 0.03519 & $a$ & 36.51 \\
\hline $\mathrm{H}$ & 6.22 & 0.062 & 1.00784 & 0.06172 & $b$ & 64.03 \\
\hline $\mathrm{O}$ & 50.16 & 0.502 & 15.999 & 0.03135 & $c$ & 32.53 \\
\hline $\mathrm{N}$ & 1.35 & 0.014 & 14.0067 & 0.00096 & $d$ & 1 \\
\hline
\end{tabular}

Table 2

DETERMINATION OF SUBSCRIPTS IN THE CHEMICAL FORMULA $\mathrm{C}_{a} \mathrm{H}_{b} \mathrm{O}_{c} \mathrm{~N}_{d}$ BASED ON ELEMENTAL ANALYSIS

Table 3

BIOGAS VOLUME, METHANE CONTENT IN BIOGAS, AND METHANE VOLUME DEPENDING ON DIGESTION TIME

\begin{tabular}{|c|c|c|c|c|c|c|c|c|c|}
\hline \multirow{2}{*}{$\begin{array}{c}\text { Time } \\
t \\
(d)\end{array}$} & \multicolumn{3}{|c|}{$\begin{array}{c}\text { Biogas volume } \\
(\mathrm{mL})\end{array}$} & \multicolumn{3}{c|}{$\begin{array}{c}\text { Methane content } \\
(\%)\end{array}$} & \multicolumn{3}{c|}{$\begin{array}{c}\text { Methane volume } \\
(\mathrm{mL})\end{array}$} \\
\cline { 2 - 11 } & $\begin{array}{c}\text { Potato } \\
\text { waste }\end{array}$ & $\begin{array}{c}\text { Potato } \\
\text { waste and } \\
\text { Chlorella } \\
\text { sp. extract }\end{array}$ & $\begin{array}{c}\text { Potato } \\
\text { waste and } \\
\text { Spirulina } \\
\text { sp. extract }\end{array}$ & $\begin{array}{c}\text { Potato } \\
\text { waste }\end{array}$ & $\begin{array}{c}\text { Potato } \\
\text { waste and } \\
\text { Chlorella } \\
\text { sp. extract }\end{array}$ & $\begin{array}{c}\text { Potato } \\
\text { waste and } \\
\text { Spirulina } \\
\text { sp. extract }\end{array}$ & $\begin{array}{c}\text { Potato } \\
\text { waste }\end{array}$ & $\begin{array}{c}\text { Potato } \\
\text { waste and } \\
\text { Chlorella } \\
\text { sp. extract }\end{array}$ & $\begin{array}{c}\text { Potato } \\
\text { waste and } \\
\text { Spirulina } \\
\text { sp. extract }\end{array}$ \\
\hline 3 & 610 & 800 & 750 & 1.80 & 0.06 & 0.01 & 10.98 & 0.480 & 0.075 \\
\hline 7 & 450 & 500 & 455 & 3.20 & 0.11 & 0.04 & 14.40 & 0.550 & 0.182 \\
\hline 10 & 260 & 215 & 210 & 37.9 & 12.8 & 0.14 & 98.54 & 27.52 & 0.294 \\
\hline 14 & 240 & 210 & 190 & 47.2 & 17.6 & 0.61 & 113.28 & 36.96 & 1.159 \\
\hline 17 & 230 & 230 & 240 & 58.4 & 21.3 & 0.87 & 134.32 & 48.99 & 2.088 \\
\hline 21 & 210 & 225 & 200 & 68.7 & 24.4 & 1.09 & 144.27 & 54.90 & 2.180 \\
\hline TOTAL & 2000 & 2180 & 2025 & - & - & - & 515.79 & 169.4 & 5.978 \\
\hline
\end{tabular}




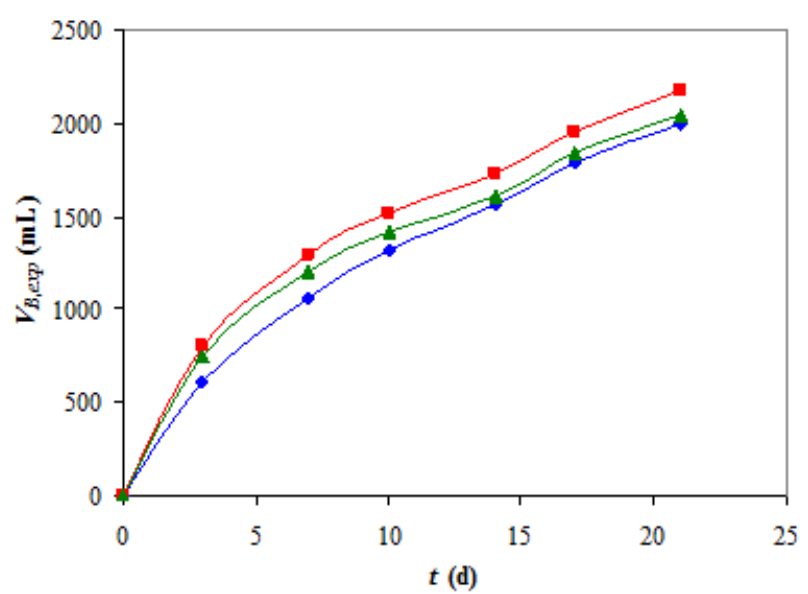

Fig. 2. Time variation of experimental cumulative biogas volume for potato waste $(\bullet)$ and potato waste with extracts of Chlorella sp. ( $(\bullet)$ and Spirulina sp. (

The inhibitory effectproduced bythe microalgal extracton the production of biomethane is highlighted in figure 3 . While the extract of Chlorella sp. caused a 3-fold decrease in the final amount of biomethane generated in the anaerobic digestion of potato residuals, Spirulina sp. had a more pronounced inhibitory effect. The biomethane potential was significantly different for the three organic fermentation mixtures. After 21 days, potato waste inoculated with manure without microalgal extract gave the best cumulative biomethane production, i.e., $P_{\text {mexp }}=148.24 \mathrm{~mL} / \mathrm{g} \mathrm{VS}$, the substrate with Chlorella sp. had, a cumulative biomethane yield of $48.65 \mathrm{~mL} / \mathrm{g} \mathrm{VS}$, and that with Spirulina sp. showed a very low cumulative biomethane production of only $1.72 \mathrm{~mL} /$ g VS.

\section{Methane-based biodegradability}

Biodegradability of potato waste, which was estimated using Eq. 4 depending on $P_{M \text { mexp }}=E B M P=148.24 \mathrm{~mL} / \mathrm{g} \mathrm{VS}$ and TBMP $=383 \mathrm{~mL} / \mathrm{g}$ VS was 0 , oxp $38.7 \%$, indicating that the biochemical processes faced some inhibitory influences. For example, increased ammonia or volatile fatty acid concentrations or too high levels of sulûde ions can have a toxic effect for methanogenesis [36, 37]. In practice, the conversion rate of organic substances is lower than the theoretical value since no ideal conditions can be fulfilled
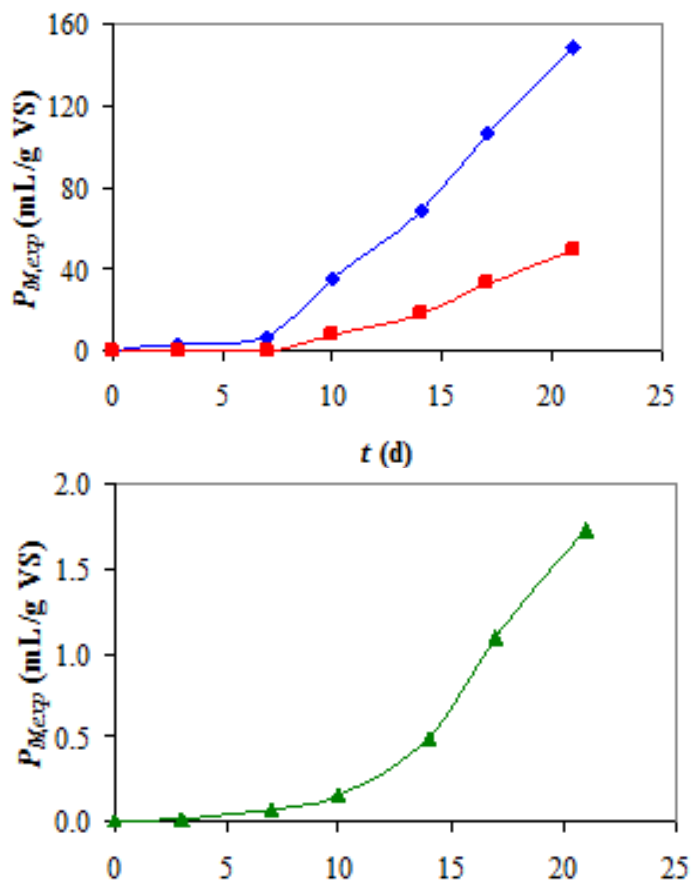

$t$ (d)

Fig. 3. Time variation of experimental cumulative methane production for potato waste $(\bullet)$ and potato waste with extracts of Chlorella sp. ( and Spirulina sp.

[38]. A likely drawback of the optimal digestion is the large amount of fast digestible compounds, e.g., starch in potato substrate, which can easily be transformed into volatile fatty acids inducing process destabilization by methanogenesis inhibition [9].

\section{Kinetic modelling}

Characteristic parameters of Cone model (eq. 5) and modified Gompert model (eq. 6), which were estimated based on experimental data using Solver add-in program (Microsoft Excel), and the values of rootmean square error (RMSE) for the substrates subjected to anaerobic digestion are summarized in table 4. Tabulated values of kinetic parameters are within the ranges reported in the related literature [26, 28, 32, 33].

Time variations of cumulative methane production $\left(P_{1}\right)$ predicted by eqs. 5 and 6 are shown in figures 4 and 5 .

\begin{tabular}{|l|l|c|c|c|}
\hline \multirow{3}{*}{ Model } & Parameter & Potato waste & $\begin{array}{c}\text { Potato waste and } \\
\text { Chlorella sp. extract }\end{array}$ & $\begin{array}{c}\text { Potato waste } \\
\text { and Spirulina } \\
\text { sp. extract }\end{array}$ \\
\hline \multirow{4}{*}{ Cone } & $P_{M m}(\mathrm{~mL} / \mathrm{g}$ VS $)$ & 277.15 & 80.03 & 2.63 \\
\cline { 2 - 5 } & $k\left(\mathrm{~d}^{-1}\right)$ & 0.050 & 0.053 & 0.054 \\
\cline { 2 - 5 } & $n$ & 2.98 & 3.83 & 4.93 \\
\cline { 2 - 5 } & $\mathrm{RMSE}$ & 2.76 & 0.90 & 0.03 \\
\hline \multirow{4}{*}{ Modified Gompertz } & $P_{M m}(\mathrm{~mL} / \mathrm{g}$ VS) & 245.83 & 83.75 & 3.28 \\
\cline { 2 - 5 } & $r_{m}(\mathrm{~mL} / \mathrm{g}$ VS/d) & 11.64 & 4.31 & 0.18 \\
\cline { 2 - 5 } & $\lambda(\mathrm{d})$ & 7.89 & 9.48 & 0.04 \\
\cline { 2 - 5 } & $\mathrm{RMSE}$ & 2.78 & 0.90 & 0.90 \\
\hline
\end{tabular}

Table 4 CHARACTERISTIC PARAMETERS OF KINETIC MODELS

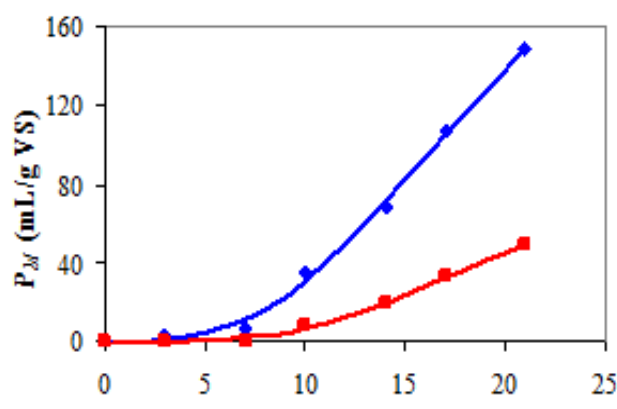

$t$ (d)

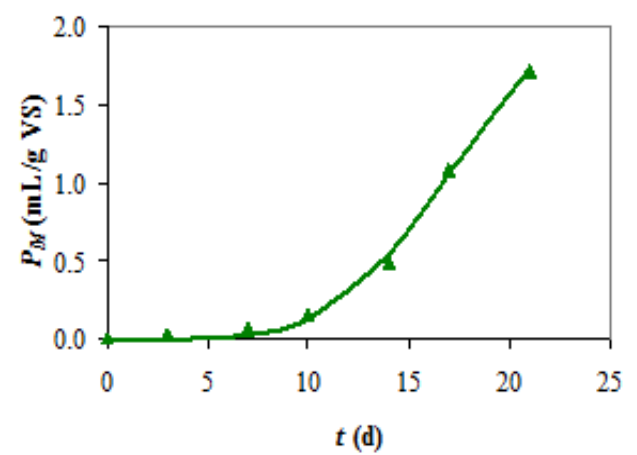

http://www.revistadechimie.ro
Fig. 4. Time variation of cumulative methane production for potato waste ( $\bullet$ ) and potato waste with extracts of Chlorella sp. (-) and

Spirulina sp. ( $\mathbf{\Delta})$ (bullets: experimental, lines: Eq. 5 (Cone model)) 


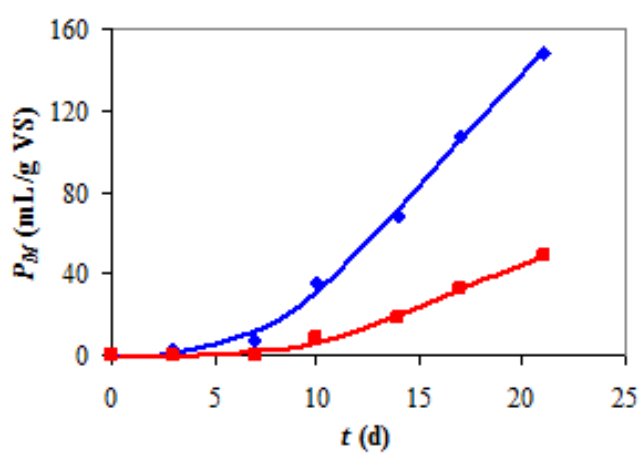

Depicted results and tabulated values of RMSE (0.03-2.78) reveal a good agreement between experimental and simulated data. Moreover, values of $P_{M}$ predicted by both models are almost identical.

Results presented in table 4 for Cone model emphasize lower values of predicted maximum methane production, $P_{M, m}$ (3.5 and 105 times), similar values of hydrolysis rate constant $\left(\mathrm{kH}^{\prime \prime} 0.05 \mathrm{~d}^{-1}\right)$, and higher levels of shape factor, $n$ (1.3 and 1.7 times), after addition of Chlorella sp. and Spirulina sp. extracts. Tabulated values of kinetic parameters for modified Gompertz model highlight lower values of $P_{M m}$ ( 2.9 and 75 times) and maximum methane production rate, $r_{m}(2.7$ and 66 times), and larger levels of lag-phase time, $\lambda^{m}$ (1.2 and 1.4 times), after addition of Chlorella sp. and Spirulina sp. extracts. Moreover, for both kinetic models, values of $P_{M . m}$ were 1.5-1.9 times higher than those of $P_{M m e x p}$ for all three substrates, whereas for anaerobic digestion of potato waste, the values of $P_{\text {m }}$ $(277.15 \mathrm{~mL} / \mathrm{g}$ VS for Cone model and $245.83 \mathrm{~mL} / \mathrm{g}$ VS for $\mathrm{m}$ modified Gompertz model) were 1.4 and 1.6 times lower than the value of TBMP ( $383 \mathrm{~mL} / \mathrm{g} \mathrm{VS}$ ).

\section{Conclusions}

Enormous amounts of food and food-processing residues are generated annually, causing many environmental problems due to their high moisture and organic contents [3]. Anaerobic digestion of food processing residuals for producing biogas with high methane content is an advantageous option in the management of organic waste, supporting environmental protection by stabilizing pollutant residues, while recovering the biomethane energy component through efficiently valorisation of starch, cellulose, and other digestible organic compounds. Besides energy recovery as biogas that can supply conventional fuels, another benefit of treating potato waste in biogas plants is to significantly reduce the level of greenhouse gases that would result from the direct decomposition of biological waste into the environment [12]. Also, anaerobic digestion generates the fermented sludge as a by-product that is a valuable ecological fertilizer [39, 40].

The present study aimed at assessing the theoretical and experimental biomethane potential of potato processing residuals as well as at studying the effects of Chlorella sp. and Spirulina sp. microalgae extracts on the anaerobic digestion process of potato waste.

After 21 days, a cumulative methane production of 148.24 $\mathrm{mL} / \mathrm{g}$ VS was obtained from potato waste inoculated with manure without microalgal extract, whereas the substrate with Chlorella sp. had a cumulative methane yield of 48.65 $\mathrm{mL} / \mathrm{gVS}$, and that with Spirulinasp. had a verylow cumulative methane yield of $1.72 \mathrm{~mL} / \mathrm{g}$ VS. The inhibitory effect of microalgal extracts on the methane production is probably due to stabilizers in the extract composition as well as to the toxic effect of ammonia generated in excess by the extract rich in nitrogen. Dynamics of cumulative methane production were accurately predicted by Cone and modified Gompert
Fig. 5. Time variation of cumulative methane production for potato waste $(\bullet)$ and potato waste with extracts of Chlorella sp. (-) and Spirulina sp. ( $\mathbf{\Delta})$ (bullets: experimental, lines: Eq. 6 (modified Gompertz model))

models. Both kinetic models could be used to design, control, and optimize the anaerobic digestion process.

Acknowledgements: This work was supported bya grant of the Romanian Ministry of Research and Innovation, CCCDI - UEFISCDI, project number PN-III-P1-1.2-PCCDI-2017-0541/ contract no. 32PCCD/2018, within PNCDI III. Also, the authors acknowledge the financial support of the Romanian Ministry of Research and Innovation through the contractno. 30PFE/2018.

\section{References}

1.OLIVEIRA, F., DOELLE, K., J ournal of Food Processing \& Technology, 6, no. 8, 2015, doi:10.4172/2157-7110.1000478.

2.KATSUYAMA, A. M., National Food Processors Association, Western Research Laboratory, Berkeley, California, 1979.

3.PISTIS, A., ASQUER, C., SCANO, E. A., Environ. Eng. Manag. J., 12, no. S11, 2013, p. 93.

4.CIOABLA, A.E., IONEL, I., TENCHEA, A., DUMITREL, G.A., PODE, V., Rev. Chim. (Bucharest), 64, no. 2, 2013, p. 186.

5.DUMITREL, G.A., CIOABLA, A.E., IONEL, I., VARGA, L.A., Rev. Chim. (Bucharest), 68, no. 11, 2017, p. 1294.

6.YAN, H., ZHAO, C., ZHANG, J., ZHANG, R., XUE, C., LIU, G., AMB Express, 2017, p. 7.

7.MOLINO, A., NANNA F, DING, Y., BIKSON, B., BRACCIO, G., Fuel, 103, 2013, p. 1003.

8.CIOABLA, A.E., DUMITREL, G.A., IONEL, I., Rev. Chim. (Bucharest), 68, no. 11, 2017, p. 2614.

9.GALVÃO, C. K. L., Dissertation Thesis, Faculdade de Ciências e Tecnologia, Universidade Nova de Lisboa, 2014.

10.) ØRGENSEN, P.)., Biogas: Green Energy, 2nd edition, PlanEnergi and Researcher for a Day, Faculty of Agricultural Sciences, Aarhus University, 2009.

11.KHAN, M.S.M., KANEESAMKANDI, Z., Int. J. Innov. Appl. Studies, 4, no. 1,2013, p. 101.

12.MUHONDWA, J.P., MARTIENSSEN, M., BURKHARDT, M., Int. J . Environ. Res., 9, no. 2, 2015, p. 481.

13.VARGA, L., CIOABLA, A.E., IONEL, I., Rev. Chim. (Bucharest), 67, no.1, 2016, p. 174.

14.DE CICCO, A., JEANTY, J.C., Eurostat Report, 2017.

15.SEPELEV, I., GALOBURDA, R., Res. Rural. Dev., 1, 2015, p. 130.

16.PARAWIRA, W., MURTO, M., ZVAUYA, R., MATTIASSON, B., Renew.

Energ, 29, 2004, p. 1811.

17.STEWART, D.J ., BOGUE, M.J ., BADGER, D.M., N. Z. JI Sci. Dunedin, 27, 1984, p. 285.

18.THORIN, E., OLSSONA, J., SCHWEDEA, S., NEHRENHEIMA, E., Energy Procedia, 105, 2017, p. 1037.

19.SCHWEDE, S., KOWALCZYK, A., GERBER, M., SPAN, R., Bioresour. Technol., 148, 2013, p. 428.

20.*** APHA-AWWA-WPCF Standards 20th edition, American Public Health Association, American Water Works Association and Water Enironment Federation, Washington DC, 1998.

21.ANGELIDAKI, I., ELLEGAARD, L., AHRING, B. K., Biotechnol. Bioeng., 39, 1992, p. 351.

22.ACHINAS, S., EUVERINK, G. J. W., Res. Efficient Tech., 2, no. 3, 2016, p.143.

23.BOYLE, W.C., Energy Recovery from Sanitary Landfills - A Review, Microbiol Energy Conversion (Eds.: Schlegel, H.G., Barnea, S.), Pergamon Press, Oxford, UK, 1976. 
24.BUSWELL, A.M., MUELLER, H.F., Ind. Eng. Chem., 44, 1952, p. 550. 25.DEUBLEIN, D., STEINHAUSER, A., Energy supply in the futurescenarios, Chapter 2, Biogas from Waste and Renewable Resources, Wiley-VCH Verlag GmbH \& Co. KGaA, Weinheim, 2008, p. 7.

26.FENG, L., LI, Y., CHEN, C., LIU, X., XIAO, X., MA, X., ZHANG, R., HE, Y., LIU, G., BioResources, 8, no. 2, 2013, p. 2487.

27.HEROUT, M., MALATAK, J., KUERA, L., DLABAJA, T., Res. Agr. Eng., 57, no. 4, 2011, p. 137.

28.NGUYEN, D.D., JEON, B.H., JEUNG, J.H., RENE, E.R., BANU, J.R., RAVINDRAN, B., VU, C.M., NGO, H.H., GUO, W., CHANG, S.W., Bioresour. Technol., 280, 2019, p. 269.

29.ELBESHBISHY, E., NAKHLA, G., HAFEZ, H., Bioresour. Technol., 110, 2012, p. 18.

30.DOBRE, T., PARVULESCU, O.C., STOICA-GUZUN, A., STROESCU, M., JIPA, I., AL JANABI, A.A.A., Int. J. Heat Mass Transfer, 103, 2016, p. 478.

31.STOICA, A., DOBRE, T., STROESCU, M., STURZOIU, A., PARVULESCU, O.C., Food Bioprod. Process., 94, 2015, p. 218.

32.HASSAN, M., UMAR, M., DING, W., MEHRYAR, E., ZHAO, C., Energy, 141, 2017, p. 2314.
33.YU, L., BIAN, C., ZHU, N., SHEN, Y., YUAN, H., Energy, 173, 2019, p. 1021.

34.BECKER, E.W., Microalgae Biotechnology and Microbiology, Cambridge Press University, 17, 1994.

35.CHISTI, Y., Trends Biotechnol., 26, 2008, p. 126.

36.DEUBLEIN, D., STEINHAUSER, A., WILEY-VCH Verlag GmbH \& Co. $\mathrm{KGaA}$, Second, Revised and Expanded Edition, 2011, p. 128.

37.ZAKARYA, I.A., ABUSTAN, I., ISMAIL, N., IZHAR, T.N.T., YUSUF, S.Y., SANDU, A.V., Rev. Chim. (Bucharest), 67, no. 4, 2016, p. 774.

38.NEVES, L., OLIVEIRA, R., ALVES, M.M., The 3rd International Symposium on Anaerobic Digestion of Solid Wastes, Munich, Germany, 18-20 September, 2002.

39.MEDINA-HERRERA, M., RODRÍGUEZ-GARCIA, A., MONTOYA HERRERA, L., CÁRDENAS-MIJ ANGO, J ., GODINEZ-MORA-TOVAR, L.A., BUSTOS-BUSTOS, E., RODRIGUEZ-VALADEZ, F.J ., MANRIQUEZROCHA, J., Int. J. Environ. Res., 8, no. 2, 2014, p. 483.

40.PARK, S., LI, Y., Bioresour. Technol., 4, 2012, p. 42.

$\overline{\text { Manuscript received: } 15.11 .2018}$ 